\title{
Phased training of technical translators and its specific features
}

\author{
Nataliya Gavrilenko - Svetlana Dmitrichenkova
}

\section{DOI: 10.18355/XL.2017.10.04.11}

\begin{abstract}
The article describes an original approach to training of technical translators. The authors present a model describing formation of translation competences in students / graduates of nonlinguistic higher schools which has been tested throughout 15 years in the Engineering Academy of the Peoples' Friendship University of Russia. Key competences of technical translators were defined, examined and systematized. In particular, these include intercultural, communicative, special, social and personal competence. The authors propose a phased approach to the formation of translation competences during fulfillment of relevant tasks by translators. This gave the possibility to point out four main training stages - professional orientation, analysis, synthesis and correction. Each tasks referring to the above stages formed the basis of the original training modules which include the following components: tasks, ways of its solution, relevant competences and external assets, certain exercises developed to check formedness of relevant knowledge and skills in the field of technical translation. The developed model has an important feature which implies integration of knowledge and skills referring to a particular industry in students / graduates of higher educational institutions.
\end{abstract}

Key words: integrative knowledge, key competences of translators, phased training model, technical translator, translation activity

\section{Introduction}

For a long time, interpreters in Russia were trained only in linguistic universities or in linguistic faculties (Belenkova and Davtyan, 2016, Alferova, 2010, Gavrilenko, 2010). Current analysis of tasks performed by translation agencies shows steady growth of demand for translation of technical texts, the growing number of translation areas and the emergence of new specialties, such as project manager, translatorlocalizer, translator-terminologist, etc. This profession is undergoing significant changes and, accordingly, it requires new approaches to training of translators. This is particularly evident in performing translations of technical texts, which, according to the French researcher Froeliger, are located at the intersection of STEM and humanitarian disciplines, presenting an "engagement of analog and digital approaches" (Froeliger, 2013).

Complexity of technical translations as opposed to the humanitarian ones lies in the fact that they require extensive knowledge of terminology and the translator's ability to translate it accurately into relevant native languages. Basic requirements for accurate translations of technical texts are as follows:

- Accurate rendering of the original text (Zhang et al., 2015, Gavrilenko, 2016, Durieux, 2010).

- Strict clarity of thought rendered in the most succinct and concise way, inherent in the scientific and technical style (Byrne, 2014, Schweitzer, 1988, Zimnyaya, 2004). Translations should not contain specific features of the original language.

- Translations should meet all standard requirements of relevant native languages (Olohan, 2015, Krueger et al., 2014, Tarasova, 2015).

Modern language is characterized by polysemy of the existing lexical units; the existing words take on new meanings (Wright, 2013, Olohan, 2015, Byrne, 2014). 
The nature of terms, as well as their sound and graphical features are subject to changes. "Cybernetic" terms, such as induction, diffraction, heterode, etc.) are replaced with words from the everyday, common lexis (program, format, failure, download, Windows, setup, etc.).

In late 1990s, the Ministry of Education of the Russian Federation approved additional Program aimed at training students / graduates of technical universities and faculties for translation activity, which implied 1500 academic hours. This approach provided the possibility to train translators specialized in translating texts in a particular field of knowledge. This article deals with a model describing formation of translating competences in students of the Engineering Academy of Peoples' Friendship University of Russia. Training was carried out throughout 15 years; key competences of technical translators were substantiated and highlighted; the sequence of relevant professional tasks was defined; phased training modules were developed. The developed model has an important feature, which implies integration of knowledge and skills referring to a particular industry in students / graduates of higher educational institutions.

Hence, the article deals with the integrative model of training industry-specific translators, which formed the basis of the developed learning platform "Translation Didactics". Theoretical and methodological components features of this study are based on complementary techniques referring to its research purpose. Namely, these include epistemological explication, conceptualization, structural and functional analysis.

The authors used dialectical and formal approaches, consistency principles, and the ascent from the abstract to the concrete along with compilation of national and international experience in relevant issues. We have conducted a comparative analysis of foreign methods for translator's preparation to determine the main competencies of a technical translator. The system method has allowed considering the procedure of professional competence formation of a translator.

\section{Key competencies of technical translators}

Professional competence of any translator is a non-uniform phenomenon. However, current translation studies have not formed a unified approach to the consideration of actual translating competences and their relevant components. The analysis of literature on translation studies shows complexity, ambiguity and diversity of interpretations referring to this concept, its structure and components. A competent translator should not only have certain knowledge, skills and abilities; he/she should be able to use them professionally in dealing with translation problems. This suggests his/her adequate motivation to perform professional activities, certain personal qualities, ethical behavior, commitment to self-development, etc.

Research sources highlight a large number of competences; many of them have different names. However, they are the same concepts in essence (Porshneva, 2004, Schweitzer, 1988, Delisle, 1992). Nevertheless, a number of studies attempted to highlight some more generalized components of these professional competences. Thus, analyzing the components of translation competences, Latyshev and Provorotov (1999) believe that the latter includes the following components:

- basic components, which generally aim at imparting "theoretical and applied knowledge of translation" to students as the basis for the development of general skills required to perform any kind of translation;

- specific components, which include knowledge, skills and abilities required to carry out some specific kinds of translation (written, consecutive, simultaneous, etc.);

- special components, which include their "parts required for translating texts of a certain genre and style: scientific, technical, business, literary, etc...".

XLinguae, Volume 10, Issue 4, October 2017, ISSN 1337-8384, eISSN 2453-711X 
A group of researchers led by Yves Gambier attempted to systematize components of translation competences. In 2009, the European Master's in Translation (EMT) was launched. The translator competence profile, drawn up by European experts, details the competences translators need to work successfully in today's market: linguistic, thematic, cross-cultural and technological skills of translators in the labor market as well as the ability to extract information from the context. In particular, extraction of context-related information gives the possibility to determine:

- meaning of a certain word (standard or technical)

- particular meaning of a specific term in the case of multivalent terms,

In addition, the context makes it possible to remove some entailed components of terms-phrases.

The proposed components of translation competences do not differ much from the competences highlighted by researchers in late 1990s.

In this respect, studies, carried out by PACTE (Process in the Acquisition of Translation Competence and Evaluation) are regarded as the most systematic and complete. The PACTE group has been carrying out empirical- experimental research into translation competence and its acquisition in written translation since 1997. The participants identified the following main components of translation competences: a bilingual, extralinguistic, instrumental, strategic, and psychophysiological (Beeby et al., 2003). This model seems somewhat controversial in terms of highlighting such multi-level concepts as mechanisms of speech activity, motivation, ability and emotional side of individual translators as part of the psycho-physiological competence. Disadvantages of this model include the absence of a competence related to the social context, which largely determines the entire translation process.

The lack of a unified approach to the consideration of components referring to professional competences of translators necessitated theoretical substantiation as regards determining key competencies for the specialty "technical translator". Key competencies are regarded as core competencies that ensure normal human life in any society (Zimnyaya, 2004). In our case, these refer to a professional translation environment.

Selection of the above competencies was determined by a number of ideas put forward in the Russian psychological and translation studies, namely:

- Professional competence includes a number of components, correlated with various labor components (Markova, 1996);

- Translators provide intercultural communication (Khaleeva, 1989);

- All competences are social, since they are generated in a certain society. They are social by their content, they appear in society (Zimnyaya, 2004);

- Professional development is determined by the formation of professionally important personality-related qualities (Markova 1996).

The above ideas gave the possibility to systematize the structure of relevant professional competences that should be inherent in translators, correlating it with the main activity components: intercultural communication, professional actions of translators, professional translation environment and the personality of a professional translator (Gavrilenko, 2016).

As a result, four core competencies of a technical translator were identified, namely:

- intercultural communicative competence as the willingness and ability (pursuant to the social and cultural norms of communication in the professional field) to understand statements provided in a foreign language and to create oral or written statements in a native language based on their understood meaning;

- special competence of a translator as the willingness and ability to perform work duties at a high level, translator's mastery of appropriate knowledge and skills in the field of translation and certain technical area and his/her ability to plan further professional development;

- social competence of a translator as an ability to carry out joint professional 
activities, mastery of professional communication techniques required for this field, social responsibility for the results of their work, etc.;

- personal competence, i.e., mastery of appropriate professionally essential personal qualities (Gavrilenko, 2016).

The mentioned components of translators' professional competences present an open structure that can be changed, supplemented with regard to further development of important aspects of this profession. Highlighted skills can be distributed to the key competencies that will give the possibility to systematize them as well as to avoid excessive fragmentation and synonymity. It should be recognized that components of the selected key competencies referring to interpreters and translators would be generally different; the same refers to translators of literary or special texts.

In accordance with the activity approach, translation competence could be formed while performing professional tasks (Butlen and Dolz, 2015).

It is pertinent to point out that a key understanding of post-modern approaches to education is that learning can no longer be seen as the intended result of a toss-andcatch, conduit or transmissionist process involving the transfer of knowledge from teacher to learner. Nor can it be regarded as a process that occurs solely within the brains of individual students (Mercer, 1992, Flannery, 1992, Bredo, 1994, Bruffee, 1995). From the perspective of contemporary cognitive science, cognition is an embodied, socially-situated and enactive process. This field of inquiry has moved away from a focus on knowledge as some sort of reified stored matter to a focus on knowing; away from the product and towards the process. From this perspective, competence is not stored away inside of craniums, it is enaction dynamically embodied in authentic activity (Biagini Boyd and Monacelli, 2017).

\section{Network analysis and translator's activity}

Synergetic approach allows considering both physical and social phenomena, studying the self-organization processes of various systems with linguistic and cultural factors, allowing visualizing their links more clearly while translating (Remkge, Nefedova and Gillespie, 2016). Moreover, this approach is regarded as «not just dynamic, but as a self-developing and self-organizing system» (Kushina and Pylaeva, 2014). Thus, we can classify it as a synergistic system and examine it within the synergetic linguistics.

The network approach, considering modern society as a network society, is one of synergistic approach manifestations. In this case, social structures of society are in the center of network research. Sociologists consider the social network as a union of social terms - social actors and their relationships. The network phenomenon is often explained by the means of a mathematical notion (graph), which may be represented as a number of nodes, connected by edges. The Social Network is a group of nodes: social actors and the relationships between them (social interaction) for resource exchange (Castells, 2003).

One can note that translator's activity is an open dynamic system, which includes many nodes-graphs with edges-links between various elements. For example, the translator himself is linked to the client and to the social environment with a target language. Specialized text is understood based on the translation analysis: communication features in a particular professional environment and social institution, which is difficult to consider out of touch with respective organizations, higher education institutions, traditions, communication ethics etc. (Kim, 2014). Communicative situation, represented by such «nodes» as the «who, where, when, for what purpose, for whom?» is a base for the source text etc. Text translation must be with due account for target language and for features of a particular reader, his occupation, the communicative situation, in which the text will be used. Each of these 
elements is related to a number of other determining factors. Online translation model is a combination of these links.

\section{Network communication in the educational context}

Translation environment for related teachers is not linear. Teacher's professional development depends on various factors: environment, personal beliefs, experiences (teaching and translation), practice etc. (Dogan, Pringle and Mesa, 2016). These factors rise in creating and implementing the pedagogical teaching models, as well as in the process of consideration, which allows the teacher to structure and generalize the pedagogical situation, to modify and adapt it to different audiences (Bernardini, 2016).

How, who and what should be combined in the educational context? Knowledge and information can be imparted through structured and unstructured channels. Such feature of a network communication as a multi-channel and cell-based structure is a significant factor in creating this context, covering a significant space. This educational platform is not limited to communication networks. Our analysis of the network actors that are able to contribute to translator's preparation in a certain way has allowed identifying four information channels.

The first channel - universities, high educational institutions were training translators. There are a lot of translation researchers, who accumulate the latest achievements in the field of professional translation and translation studies. These organizations distribute the standards of professional behavior and information about the best material, contributing to a formation of a database involving scientific and practical publications, translation resources, addresses and resumes of different teachers, their service assess terms, etc. Teachers in the field of translation help the students to develop their own styles of learning to achieve the set goals (Biel, 2011).

Currently, the growth of scientific knowledge in these areas is much lower than the increase of researchers. The major part of scientists is required to «hold» the current level of knowledge and education. The necessity to consider translator's activities from the integrative point leads to the process of narrowing the range of issues under consideration. Thus, something important may be missed.

By the way, graduates of translator-training programs in Turkey were asked how well academic training prepared them for professional work. Thus, slightly over half of the respondents (51.7\%) agreed that the academic training had prepared them fairly well. $12.4 \%$ affirmed that the training prepared them extremely well for professional work, whereas $34.8 \%$ of the respondents said that the academic training had provided only basic preparation (Gümüs, 2017).

The second channel - knowledge and strategies for organizational and professional solutions can be gained in professional associations, associations of translators, translation-related websites, from professional translators and free-lancers. This channel may involve specific issues on learning translation, online training programs, developed by translation and interpreting companies that are happy to consult those, who are willing to speak about own skills and demonstrate them in practice, etc.

The third channel - information can be gained by means of a network involving translation and interpreting companies and organizations that are often using translation services. Such networks are used to find solutions on different problems, provided by clients, consumers and members of translation and interpreting companies. They relay information about innovations in the administrative law, about technological innovations, terminological databases, new translation engines etc., as they are important in translator's activity.

The fourth channel - a group of network managers is necessary to serve the network, as they introduce devices and technologies that help to teach and learn specialized translation, as well as provide the assess to available resources and their network security. 
One can note that such network's feature as a cell-based structure makes it possible to present the learning material in the form of modules. Module technology is widely used in modern high educational institutions. Experts in the field of module education allocate its various elements: module as a package of learning material, as a training unit, as an information block, as a set of academic disciplines, as a program for professional training, etc. (Gulati, 2008, Zaidan and Callison-Buch, 2011). Module allows preserving the integrity of learning material and its assimilation in structural elements. For example, there is developed a PCTD (personal creative thinking development) system that was implemented in a number of universities in the field of engineering education. It is based on module learning. Module is a part of educational program that synthesizes transdisciplinary issues and problems.

Technical translators often use on-line bilingual and multilingual tools based on parallel corpora or translation memories because of the immediate translation solutions they offer, although these resources have some drawbacks that will be described later on (Acuña, 2016). But on-line bilingual concordances and resources based on translation memories are not always accurate from the point of view of terminology, and the language they include does not always sound natural to a native speaker. This applies mainly to widely-spoken languages encompassing different dialectal varieties (Rodríguez, 2016).

\section{Modular approach to the formation of professional competences in technical translators}

Many researchers note that translation competence implies a special "translating" command of two languages (at least): receptive mastery of the source language and reproductive mastery of the language of translation, at which languages are projected onto each other (Porshnev, 2004, Schweitzer 1988). Competence approach in teaching translation involves the relationship and interaction of personality and activity components. Any professional activity takes place in a specific social context; therefore, the activity approach to teaching implies staged (phased) formation of translation competence while solving problems faced by translators. For example, learning a foreign language with the use of information technology could be implemented through a phased approach, highlighting the macro and micro-tasks. Macro-tasks should be addressed within a social context, creating preconditions for communication and interaction with other participants in the teaching and learning process, bringing it closer to a real professional communication. Solution of microtasks implies performance of the required operations and proceeds more independently and individually (Grosbois, 2013).

Analysis of research papers and monitoring of technical translation activities allowed clarifying the sequence of relevant tasks (Korol'kova et al. 2016, Durieux 2010, Ladmiral, 2015). Of course, an experienced translator may omit some tasks, but this algorithm of professional activities gives the possibility to provide certain sequence of training materials and to propose appropriate methods and techniques that enable formation of translation competences. The above translation tasks are distributed among four training (stages) phases:

- vocational-orienting stage - finding a job, obtaining the text from the employer (for subsequent translation), getting ready for translation;

- analytical stage - understanding and interpretation of the source text (information-reference search and translation analysis of the text), translation strategy development;

- synthesizing stage - search for relevant terms, similarity matching and translation of the text based on the understood foreign language text;

- corrective phase - correction, editing and forwarding the translated text to the customer (Gavrilenko, 2016).

XLinguae, Volume 10, Issue 4, October 2017, ISSN 1337-8384, eISSN 2453-711X 
The modular approach to training is widely used in modern higher educational institutions. Modular education experts identify its various components: modules as learning material packages, as a training unit, as the unit of information, as a set of academic disciplines, as a professional training program related to a particular profession, etc. (Makarova, 2007). Modules allow keeping integrity of the educational material; they ensure its assimilation due to individual structural elements. For example, the DICT system (development of individual creative thinking) referring to engineering education has already been developed and implemented in a number of universities. Modular learning is among its key principles. A module is understood as part of a training program that synthesizes issues and problems at the intersection of different disciplines.

The developed training model for technical translators provides a somewhat different interpretation of the module: each professional tasks of a translator is the basis of the training module. All components of translation competence were consistently correlated with clearly defined tasks. As a result, each of the resulting training modules contained formulated translation tasks along with professional knowledge, skills and required qualities (Gavrilenko 2010). For example, this modular technology is implemented in a model of ICT-based technical translation learning developed by Alferova (2010). Each training module of this training system includes the following components:

- Purpose unit, which includes translation tasks and a didactic purpose being perceived as an important learning outcome.

- Information unit presenting the list of IT assets recommended for solving translation problems, indicating developers, links and URL-addresses, as well as the information on aspects related to relevant translation tasks, which is critical for the future translator.

- Methodical unit, describing IT knowledge and skills required for solving a specific translation problem; i.e., the IT-based solution algorithm.

- Operational-activity unit, which includes two groups of exercises aimed at the formation of relevant knowledge, skills and abilities in students.

- Controlling unit, which includes exercises designed to control formation of the required IT-based professional knowledge and translation skills.

Thus, the developed training model implies the fact that each training module includes a specific macro problem, ways of its solution, relevant IT resources, necessary competences, set of exercises, ways of checking the level of formed competences, the possibility to communicate with other students, practicing translators, and teachers. This interactive learning gives students the possibility to get familiar with other cultures while communicating with their relevant representatives, to discuss translation difficulties with native speakers, etc. This kind of communication raises motivation, everyone can assist and get relevant assistance; it provides the possibility to develop interoperability, teamwork, etc. Alternately, when working with micro-objectives, the ability of autonomous operation is largely formed. The described approach to training translators required the analysis of professional knowledge and skills in the field of engineering specialties in students of nonlanguage universities, which can be helpful in forming key competences of translators.

It should be noted that students of non-language higher schools already have certain knowledge and skills referring to their major field of study by the beginning of language training. Translators, who are specialist in the subject area of the source text, have more prerequisites for the proper understanding and interpretation of technical texts with a view to their subsequent translation into native languages (Alferova, 2010). Subject knowledge is helpful in terms of fill the "gap" of linguistic knowledge in translations of source texts. These skills and knowledge can and should be used in the training process, keeping in mind complex activities of translators. This "transfer" 
of knowledge from one professional field into another can be defined as "integrative knowledge". Integrative knowledge is understood as a generalized knowledge of a set of disciplines that make up a complete system with an interdisciplinary structure. Integrative knowledge aims at overcoming fragmentation of training, activation of cognitive activity, formation of interrelated knowledge and development of creativity elements. Technical translators need the ability to mobilize the existing subject knowledge, knowledge related to professional communication specifics and to use them selectively in their professional translation.

It is noted that the translator has to be proficient in original language in order translate the text correctly (Zimnyaya, 2004). In this method of teaching, this challenge is present in the analytical stage.

The translator also has to understand the terminology and abbreviations (Froeliger, 2013), since Russian abbreviations and their English spelling differ, for example:

CAD (computer-aided design) - CAПР (система автоматизированного проектирования)

RCS (radar cross section) - ЭПР (эффективная площадь рассеивания) Incorrect interpretation will entail the loss of meaning of the whole text. Therefore, there is a synthesizing stage in the studied program.

The last stage of training teaches the translators to verify their texts. This reduces the chance for an error.

Therefore, formation of professional competence in technical translators should be based on professional competence of students in their major field of study. The analysis of professional knowledge and special skills related to engineering, envisaged by the State Standard gave the possibility to compare them with the knowledge and skills related to translation competences and to identify those that have been already formed or are formed by the beginning of language training.

These formed or emerging knowledge and skills include:

- Subject knowledge in a particular field of science and technology;

- Communicative competence in both native and foreign languages;

- Discursive competence in the field of the Russian language specialty;

- Sociocultural competence in scientific and technological communication in Russia;

- Knowledge of information technology;

- Ability to interact with related professionals.

Monitoring of the training process as regards technical translators revealed professional knowledge and skills of students that have been acquired in the course of specialized training, which demand additional emphasis of translators. Such knowledge and skills include:

- Ability to use a computer when finding the necessary information;

- Knowledge of the history of scientific and technological development in Russia, which should be supplemented by knowledge of the history of science and technology in the country of the target language;

- Knowledge of communication peculiarities specific to a professional environment in Russia, which should be complemented with knowledge of professional communication specifics in the country of the target language;

- Knowledge of the Russian language specifics as a specialty, which should be complemented with knowledge of the language specialty in the country of the target language.

The above knowledge and skills in engineering professions should be integrated into training of technical translators.

G. Kingscott (2002) argues that in the last ten or twenty years the impact of software localisation has changed the world translation business, and we have seen emerging for the first time the first multinational translation companies: «There are now six of

XLinguae, Volume 10, Issue 4, October 2017, ISSN 1337-8384, eISSN 2453-711X 
these companies: Berlitz, Bowne, Lionbridge, RWS-Polyglot, SDL and Star, all with a turnover well in excess of 50 million US dollars a year. These companies are taking more and more of the market, certainly for big projects, and all without exception grew to their present size from the boom in software localisation. Some universities are now starting to offer specific localisation courses, instead of courses in translation. Localisation courses are offered at the University of Quebec at Hull in Canada, the University of Washington in the USA, the University of Limerick in Ireland, and the Institut Supérieur de Traducteurs et Interprètes in Brussels. Worldwide activities in localisation are coordinated by the Localisation Industry Standards Association, which has its head office in Sawitzerland».

\section{Conclusion}

Thus, the purpose of the developed integrated model of teaching technical translation is to form professional competences of translators, which implies his/her willingness and ability to do professional translations using internal (core competences - intercultural, special, social and personal) and external assets. The authors of this study propose to form this competence in addressing translation problems through a staged (phased) approach. Each task forms the basis of relevant training modules; each training module includes a specific macro problem, ways of its solution, relevant IT resources, necessary competences, set of exercises, and ways of checking the level of formed competences, the possibility to communicate with other students, practicing translators, and teachers. Formation of professional competence in technical translators should be based on professional competence of students in their major field of study, which involves integration of knowledge and skills in the training process.

Summing up the results of training students / graduates of non-language higher schools throughout 15 years showed effectiveness of the developed modular training model. However, it should be noted that not all students were able to achieve the required level of professional competence in consecutive interpreting keeping in mind time span envisaged by the State Standard. Therefore, only $30-45 \%$ of all students enrolled in consecutive technical translations could do that professionally. Nevertheless, it seems appropriate that the basics of consecutive interpretation be taught within the discussed training program since basic knowledge and skills will enable further specialization of relevant graduates in their subsequent technical translations. Specific tests have been developed with a view to determine student abilities referring to interpretation. Such testing is conducted at the end of the second (analytic) phase of training. It is aimed at giving students the possibility to specialize either in translation or in interpretation (this approach is used in the training of philologists-translators) which should be indicated in the certificate, which includes the list of attended specialized courses. This modular model of training technical translators is presented in the learning platform being developed.

\section{Bibliographic references}

ACUNA, E. F. 2016. Specialised bilingual and multilingual Italian/Spanish lexicography and specialised translation teaching. Translation and Translanguaging in Multilingual Contexts, 2(1), 66-91.

ALFEROVA, D.A. 2010. "Modular Technical Translation Teaching Using Information Technology". PhD thesis. Moscow. 272.

BEEBY, A. - FERNANDEZ RODRIGEZ, M. - FOX, O. - HURTADO ALBIR, A. NEUNZIG, W. - OROZCO, M. - PRESAS, M. - RODRIGEZ INES, P. ROMERO, L. 2003. "Building a translation competence model". Benjamins Translation Library 45: 43 - 68. 
BELENKOVA, N. - DAVTYAN, V. 2016. "Correlation of Translation and Other Language Activities". International Journal of Environmental and Science Education 11(18): 10951-10959.

BERNARDINI, S. 2016. Discovery learning in the language-for-translation classroom: corpora as learning aids. Cadernos de Tradução, 36(SPE), 14-35.

BIAGINI, M. - BOYD, M. S. - MONACELLI, C. (EDS.). 2017. The Changing Role of the Interpreter: Contextualising Norms, Ethics and Quality Standards. Taylor \& Francis.N 15038: 2006 standard of translation services and its training implications. The Journal of Specialised Translation, 16, 61-76.

BIEL, Ł. 2011. Training translators or translation service providers? EN 15038: 2006 standard of translation services and its training implications". Journal of Specialised Translation, 16, 61-76.

BREDO, E. 1994. Reconstructing Educational Psychology: Situated Cognition and Deweyan Pragmatism. Educational Psychologist 18.1 : 23-35.

BRUFFEE, K. A. 1995. Collaborative Learning: Higher Education, Interdependence and the Authority of Knowledge. Baltimore: Johns Hopkins University Press.

BUTLEN, M. - DOLZ, J. 2015. The logic of skills: critical reviews. The Logic of Competencies: Critical Looks. French Today. Paris: Armand Colin, 3-11.

BYRNE, J. 2014. Scientific and technical translation explained: a nuts and bolts guide for beginners. Routledge.

CASTELLS, M. 2003. The Power of Identity: The Information Age: Economy, Society, and Culture Volume II. Wiley-Blackwell.

DELISLE, J. 1992. "Translation manuals: classification test". TTR, 1: 17-47.

DOGAN, S. - PRINGLE, R. - MESA, J. 2016. The impacts of professional learning communities on science teachers' knowledge, practice and student learning: a review. Professional Development in Education, 42(4), 569-588.

DURIEUX, C. 2010. Educational basis of technical translation. Paris: The house of the dictionary, 181.

FLANNERY, J. L. 1992. The Teacher as Co-conspiritor: Knowledge and Authority in Collaborative Learning. Collaborative Learning: Underlying Processes and Effective Techniques. San Francisco: Jossey Bass, 15-24.

FROELIGER, N. 2013. The wedding of analog and digital. Pragmatic translation. Paris: Les Belles Lettres, 294.

GAVRILENKO, N.N. 2010. Modular approach to translation teaching in the field of professional communication. Bulletin of Moscow State Linguistic University "Innovative approaches in foreign language teaching" M.: Rema, Series "Jurisprudence" 12(591): 122-130.

GAVRILENKO, N.N. 2016. "Methods to realize competence-building approach while teaching translation". Mathematic Education 11(7): 2151-2161.

GROSBOIS, M. 2013. Didactics of languages and technologies. From EAO to social networks. Paris: Presses of the Paris-Sorbonne University, 177.

GULATI, S. 2008. Technology-enhanced learning in developing nations: A review. The International Review of Research in Open and Distributed Learning, 9(1).

GUMUŞ, V. Y. 2017. Training Translators for the Market in Turkey: What Should We Teach to Future Translators? International Journal of Comparative Literature and Translation Studies, 5(1), 1-10.

KHALEEVA, I.I. 1989. Fundamentals of the theory of foreign speech understanding. M.: Higher School, 238.

KIM, J. H. 2014. Foreign Language Learner's Native Culture and Translation. Information, 17(12), 6137.

KINGSCOTT, G. 2002. Technical translation and related disciplines. Perspectives: Studies in translatology, 10(4), 247-255. 
KOROL'KOVA, S.A. - NOVOZHILOVA, A.A. - SHEIKO, A.M. 2016. Arsenal of a modern interpreter: information technology and Internet resources. Translator of the twenty-first century - discourse agent: multi-authored monograph. Ed. by V.A. Mityagin, A.A. Gureev. M.: FLINT: Nauka, 153-239.

KRUEGER, R. 2014. Exploring the interface between scientific and technical translation and cognitive linguistics the case of explicitation and implicitation. Thesis. University of Salford.

KUSHNINA, L. V. - PYLAEVA, E. M. 2014. Ecology of translation: contemporary trends and approaches. Perm University Herald. Russian \& Foreign Philology, (2).

LADMIRAL, J.R. 2015. Translation: from experience to reflection. The experience of translating. Under the direction of Mohammed Jadir and Jean-Réné Ladmiral. Paris: Honoré Champion, 71-82.

LATYSHEV, L.K. - PROVOROTOV, V.I. 1999. The structure and content of training translators in language higher schools. Voronezh: Publishing house ROSI, 136.

MAKAROV, A.V. 2007. Modular training: an analytical survey. M.: Higher School, 3, $66-67$.

MARKOVA, A.K. 1996. Psychology of professionalism. M.: "Knowledge", 308.

MERCER, N. 1992. Culture, Context and the Construction of Knowledge in the Classroom. Context and Cognition. Ways of Learning and Knowing, Hemel Hampstead, Herfordshire: Harvester Wheatsheaf, 28-46.

OLOHAN, M. 2015. Scientific and technical translation. Routledge.

PORSHNEVA, E.R. 2004. Interdisciplinary basics of linguistic training of translators. Doctoral thesis. Kazan, 425.

REMKHE, I. N. - NEFEDOVA, L. A. - GILLESPIE, D. C. 2016. From Function to System: Advances in Choosing a Matrix Structure of the Translation Process. Russian Journal of Linguistics, 20(3), 230-242.

RODRIGUEZ, C. I. L. 2016. Using corpora in scientific and technical translation training: resources to identify conventionality and promote creativity. Cadernos de Tradução, 36(spe), 88-120.

SCHWEITZER, A.D. 1988. Translation theory: status, issues, and aspects. M.: Nauka, 216.

TARASOVA, E.S. 2015. "Technical Translation Teaching to the Engineering Students (by the Example of Patent Descriptions)". Mediterranean Journal of Social Sciences 6(3): 350 .

WRIGHT, S.E. 2013. Scientific and technical translation. The Encyclopedia of Applied Linguistics.

ZHANG, X. - TAO, S. - GONG, ZH. - WU, B. - WANG, R. - WILAMOWSKI, B. M. 2015. An improved English to Chinese translation of technical text. Intelligent Engineering Systems (INES), 2015 IEEE 19th International Conference, 79 - 83.

ZIMNYAYA, I.A. 2004. Key competences as a result-purpose basis of competence approach to education. M.: Research center of quality of training problems, 42.

Words: 5678

Characters: 40572 (22,5 standard pages)

Assoc. Prof. Svetlana Vladimirovna Dmitrichenkova,

Doctor of Pedagogical sciences.

Peoples' Friendship University of Russia (RUDN University)

Varshavskoe sh. 47, 1,118

115230 Moscow

Russia

sw.wl@mail.ru 
Nataliya Nikolaevna Gavrilenko

Doctor of Pedagogical sciences

Professor of Foreign Languages Department of Engineering Academy

in Peoples' Friendship University of Russia (RUDN University),

Bolchoy Kozihinsky 27-1-18, 123001 Moscow,

Russia

gavrilenko.nta@gmail.com 